\title{
Poisoning with Soranjan (Colchicum): a case report
}

Mitra Rahimi ${ }^{1}$, Fatemeh Razavi², Mahtab Hajian², Amir Noyani ${ }^{3 *}$

${ }^{1}$ Toxicological Research Center, Excellence Center of Clinical Toxicology, Department of Clinical Toxicology, Loghman Hakim Hospital, Shahid Beheshti University of Medical Sciences, Tehran, Iran

${ }^{2}$ Student Research Committee, School of Medicine, Shahroud University of Medical Sciences, Shahroud, Iran

${ }^{3}$ Clinical Research Development Unit, Imam Hossein Hospital, Shahroud University of Medical Sciences, Shahroud, Iran

*Corresponding author: Amir Noyani, Assistant Professor of Emergency Medicine

Received date: March 10, 2021; Accepted date: April 22, 2021; Published date: April 28,2021

Citation: Mitra Rahimi, Fatemeh Razavi, Mahtab Hajian, Amir Noyani, (2021) Poisoning with Soranjan (Colchicum): a case report. . J. Archives of Medical Case Reports and Case Study. 4(2); DOI:10.31579/2692-9392/039

Copyright: (C) 2021 Xiao-ping Luo, This is an open access article distributed under the Creative Commons Attribution License, which permits unrestricted use, distribution, and reproduction in any medium, provided the original work is properly cited.

\section{Abstract}

Introduction: Colchicine, which is derived from a herb called Colchicum is a medication used to treat gout. Colchicum itself can act as a deadly toxic herb in the case of over dose. This is a case report study which investigates a patient who was poisoned with Colchicum (Soranjan, what it is called in Iran).

Description: The patient was a 44-year-old man who came to the emergency poisoning ward after a day of mountaineering and eating Soup. He had severe nausea and vomiting. The patient was admitted to the ICU two days later with a toxic general condition, complaining of chest pain, nausea, vomiting and shortness of breath. The patient lab tests showed elevated liver enzymes and pancytopenia. The patient respiratory distress developed and physician had to intubate the patient. The patient was treated with antibiotics, GCSF for pancytopenia and antioxidant to protect the liver.

Conclusion: The patient responded to broad spectrum antibiotic, antifungal and GCSF. paying attention to the patient's history was the key of success to diagnosis.

Keywords: toxicology; poisoning; colchicine; emergency medicine

\section{Introduction}

Colchicine is a well-known medication for the treatment of gout and fever, whose treatment and toxicity spectrum is unknown.
Colchicum speciosumis (figure 1) a species of flowering plant in the family Colchicaceae, native to mountainous areas of northern Turkey, the Caucasus and northern Iran.

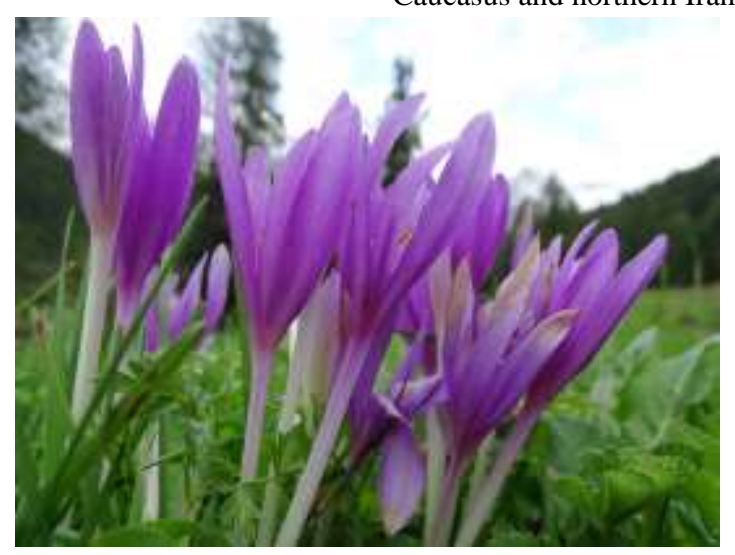

Figure 1: Naked ladies planet (Colchicum)

Kingdom:Plantae

Clade:Tracheophytes

Clade:Angiosperms
Clade:Monocots

Order:Liliales

Family:Colchicaceae

Genus: Colchicum

Species: C. speciosum 
It is taken orally and absorbed by the digestive tract and enters the bloodstream through the liver. Colchicine at the cellular level prevents endocytosis and exocytosis of cells and can damage all cells by this intracellular mechanism [1] Usually within the first 24 hours patients present with gastrointestinal complaints such as nausea and vomiting, but over time that may take from one day to 7 days, the patient proceed to multiple organ damage and even death. And the recovery process may take up to several weeks. Associated with the use of hepatic drugs such as clarithromycin or the use of herbs containing colchicine [3 and 4]. In this study, we report a patient with an herbal medicine containing colchicine called Soranjan.

\section{Description:}

The patient was a 44-year-old man who came to the emergency room one day after eating Soup which was made with Soranjan..The patient complained of nausea and vomiting. In physical examination the patient was alert, the pupil examination was normal, the lungs were clear, the patient's abdomen was soft, and no evidence of organomegaly was observed. The patient lab tests were normal. (Table 1).

\begin{tabular}{|c|c|c|}
\hline & Patient & Normal Range \\
\hline $\mathrm{Hb}$ & $11 \mathrm{~g} / \mathrm{dl}$ & $13-18(\mathrm{male}) \mathrm{g} / \mathrm{dl}$ \\
\hline $\mathrm{WBC}$ & $4500 * 10^{3} / \mathrm{mm}^{3}$ & $4.3-10.8 * 10^{3} / \mathrm{mm}^{3}$ \\
\hline PLT & $290 * 10^{3} / \mathrm{mm}^{3}$ & $150-450 * 10^{3} / \mathrm{mm}^{3}$ \\
\hline $\mathrm{LDH}$ & $760 \mathrm{u} / \mathrm{l}$ & $50-480 \mathrm{u} / \mathrm{l}$ \\
\hline $\mathrm{Cr}$ & $1.4 \mathrm{mg} / \mathrm{dl}$ & $0.6-1.2(\mathrm{male}) \mathrm{mg} / \mathrm{dl}$ \\
\hline AST & $123 \mathrm{u} / \mathrm{l}$ & Up to $37 \mathrm{u} / \mathrm{l}$ \\
\hline ALT & $101 \mathrm{u} / \mathrm{l}$ & Up to $41 \mathrm{u} / 1$ \\
\hline Bill T & $1 \mathrm{mg} / \mathrm{dl}$ & Up to $1.2 \mathrm{mg} / \mathrm{dl}$ \\
\hline Na & $136 \mathrm{meq} / 1$ & $135-145 \mathrm{meq} / \mathrm{l}$ \\
\hline $\mathrm{K}$ & $3.9 \mathrm{meq} / \mathrm{l}$ & $3.5-5 \mathrm{meq} / 1$ \\
\hline PT & $11 \mathrm{sec}$ & $10-12 \mathrm{sec}$ \\
\hline PTT & $27 \mathrm{sec}$ & $30-45 \mathrm{sec}$ \\
\hline INR & 0.7 & $1-2$ \\
\hline Digoxin Level & $0.17 \mathrm{ng} / \mathrm{ml}$ & $0.4-2 \mathrm{ng} / \mathrm{ml}$ \\
\hline Cholin Sterase & $8105 \mathrm{U} / \mathrm{grHb}$ & $71-292 \mathrm{U} / \mathrm{grHb}$ \\
\hline
\end{tabular}

Table 1: the first day after ICU admission lab test

The patient was discharged from the emergency room after symptomatic treatment.

Two days after discharge, the patient returned to the emergency room with general malaise, shortness of breath, chest pain and vomiting. The patient was toxic and complained of chest pain. Examination head and neck showed oral Aphthous. The cardiologist discharged the patient after showing normal ECG and receiving negative troponin. He was then referred to toxicology ward because his history. The patient respiratory distress developed. The ABG showed evidence of acidosis, after few days pancytopenia developed and the patient showed multi organ failure (Table 2).

\begin{tabular}{|c|c|c|}
\hline Lab Test & Patient & Normal Range \\
\hline $\mathrm{Hb}$ & $9 \mathrm{~g} / \mathrm{dl}$ & $13-18(\mathrm{male}) \mathrm{g} / \mathrm{dl}$ \\
\hline WBC & $800^{*} 10^{3} / \mathrm{mm}^{3}$ & $4.3-10.8 * 10^{3} / \mathrm{mm}^{3}$ \\
\hline PLT & $144000^{*} 10^{3} / \mathrm{mm}^{3}$ & $150-450 * 10^{3} / \mathrm{mm}^{3}$ \\
\hline LDH & $800 \mathrm{u} / \mathrm{l}$ & $50-480 \mathrm{u} / \mathrm{l}$ \\
\hline $\mathrm{Cr}$ & $2.3 \mathrm{mg} / \mathrm{dl}$ & $0.6-1.5(\mathrm{male}) \mathrm{mg} / \mathrm{dl}$ \\
\hline AST & $135 \mathrm{u} / \mathrm{l}$ & Up to $37 \mathrm{u} / \mathrm{l}$ \\
\hline ALT & $121 \mathrm{u} / \mathrm{l}$ & Up to $41 \mathrm{u} / \mathrm{l}$ \\
\hline Bill T & $1 \mathrm{mg} / \mathrm{dl}$ & Up to $1.2 \mathrm{mg} / \mathrm{dl}$ \\
\hline Na & $150 \mathrm{meq} / \mathrm{l}$ & $135-145 \mathrm{meq} / \mathrm{l}$ \\
\hline $\mathrm{K}$ & $4.3 \mathrm{meq} / \mathrm{l}$ & $3.5-5 \mathrm{meq} / \mathrm{l}$ \\
\hline PT & $11 \mathrm{sec}$ & $10-12 \mathrm{sec}$ \\
\hline PTT & $27 \mathrm{sec}$ & $30-45 \mathrm{sec}$ \\
\hline INR & 0.7 & $1-2$ \\
\hline Blood Sugar & $89 \mathrm{mg} / \mathrm{dl}$ & $60-199 \mathrm{mg} / \mathrm{dl}$ \\
\hline Troponin & $\mathrm{Neg}$ &
\end{tabular}


Table 2: Three day after ICU admission lab test

The patient's white blood cell count reached to 800 . At the same time, as the patient's respiratory condition deteriorates, the patient was intubated and the patient fever rose after intubation. Internal Medicine, infectious and Hematology consults were requested, treatment was started with a broad-spectrum antibiotic and antifungal (Meropenem, Vancomycin and Amikacin) and GCSF (8 MCG / kg / daily). The Drugs were discontinued after patient's fever dropped and white blood cell count reaches to 1500 after approximately one week of antibiotic and GCSF administration. Also he was transferred to the ward, after oral tolerance, he was discharged after one week and he was treated with oral antioxidant. $\mathrm{He}$ was then followed up by checking CBC and liver enzymes weekly.

\section{Discussion and conclusion:}

For diagnosing poisoning with Colchicum, it is important to be aware of it's toxicity and to know it's symptoms, due to its high mortality [5]. Gastrointestinal symptoms in up to $80 \%$ of patients were shown in the studies [6], which should be considered as an important early sign and patients should be evaluated periodically until they are discharged. In this case nausea and vomiting were reported. One study by Yaron Finkelstein and et al. showed Colchicine poisoning presents in three usually overlapping phases: 1) 10-24 h after ingestion is considered as the gastrointestinal phase which mimicks gastroenteritis. It may be absent after intravenous administration; 2) $24 \mathrm{~h}$ to 7 days after ingestion is considered as the multi-organ dysfunction phase. Death results from rapidly progressive multi-organ failure and sepsis. These late features include tachypnoea, electrolyte disorders (e.g. hypocalcaemia, hypophosphataemia), hypovolaemia, haematological effects (e.g. leukopaenia, thrombocytopaenia), cardiac dysrhythmias, renal failure and liver damage $[1,9,10]$. Delayed presentation, pre-existing renal or liver impairment are associated with poor prognosis. 3) Recovery which typically occurs within a few weeks of ingestion, and is generally a complete recovery barring complications of the acute illness [1]. The study of François Roubille showed evaluating renal function and blood cell count must be done before treatment, during the first month, and whenever initiating a new drug which is likely to induce interactions or if any clinical events occur involving hepatic dysfunction or renal impairment [6]. Borron SW and et al. explained that Gastrointestinal decontamination with gastric lavage and activated charcoal is often performed, and may help despite colchicine being rapidly absorbed because there is a extensive enterohepatic recirculation [7]. In the study of Jayaprakash, it was discussed that, there is no specific antidote for colchicine when taken in overdose and treatment options are limited. Haemodialysis and haemoperfusion are not effective because colchicine has a large volume of distribution, binds significantly to plasma proteins and has rapid distribution. [10] Consequently, it is important that efforts should be made to remove any remaining colchicine because the retrieval of even small amounts can greatly benefit prognosis [8]. Supportive treatments including administration of granulocyte colony-stimulating factor are the mainstay of treatment [1]

Since colchicine poisoning does not have a specific pattern or toxidrome, it is important to ask for a history of ingesting colchicine-containing plants or food.

\section{TAKE HOME MESSAGES}

With regard to the increasing use of herbal drugs, it is important to pay attention to three points: one is the patient's biography, in this case if the biography was not asked, doctors' diagnosis was completely wrong. And secondly, not all herbal drugs are safe. Finally, GCSF can be considered to treat pancytopenia in similar patient.

\section{Acknowledgments}

The authors of the article would like to thank the Clinical Research Development Unit of Imam Hossein Hospital for providing the funding help for the project. This article is based on a research project with the code of ethics: IR.SHMU.REC.1399.016 at Shahroud University of Medical Sciences.

Conflict of interests:

None to declare.

\section{References:}

1. Finkelstein Y, Aks SE, Hutson JR, Juurlink DN, Nguyen P, Dubnov-Raz G, et al. Colchicine poisoning: the dark side of an ancient drug. Clinical toxicology. 2010;48(5):407-414.

2. Rollot F, Pajot O, Chauvelot-Moachon L, Nazal EM, Kélaïdi C, Blanche P. Acute colchicine intoxication during clarithromycin administration. Annals of Pharmacotherapy. 2004;38(12):2074-2047.

3. Akdag I, Ersoy A, Kahvecioglu S, Gullulu M, Dilek K. Acute colchicine intoxication during clarithromycin administration in patients with chronic renal failure. Journal of nephrology. 2006;19(4):515-517.

4. Hirayama I, Hiruma T, Ueda Y, Doi K, Morimura N. A critically ill patient after a colchicine overdose below the lethal dose: a case report. Journal of medical case reports. 2018;12(1):191.

5. Maxwell M, Muthu P, Pritty P. Accidental colchicine overdose. A case report and literature review. Emergency Medicine Journal. 2002;19(3):265-266.

6. Roubille F. Colchicine Toxicity: Deadly Face of a Familiar Friend. The Journal of Musculoskeletal Medicine (Online). 2013.

7. Borron SW, Scherrmann J, Baud FJ. Markedly altered colchicine kinetics in a fatal intoxication: examination of contributing factors. Human \& experimental toxicology. 1996;15(11):885-890.

8. Murray S, Kramlinger K, McMichan J, Mohr D, editors. Acute toxicity after excessive ingestion of colchicine. Mayo Clinic Proceedings; 1983.

9. Waitemata District Health Board. Colchicine - safe prescribing - toe the line!! Saferx. 2011.

10. Jayaprakash V, Ansell G, Galler D. Colchicine overdose: the devil is in the detail. N Z Med J 2007;120:U2402. 
This work is licensed under Creative Commons Attribution 4.0 License

To Submit Your Article Click Here: Submit Article

DOI: $10.31579 / 2692-9392 / 039$
Ready to submit your research? Choose Auctores and benefit from:

* fast, convenient online submission

* rigorous peer review by experienced research in your field

* rapid publication on acceptance

* authors retain copyrights

* unique DOI for all articles

* immediate, unrestricted online access

At Auctores, research is always in progress.

Learn more www.auctoresonline.org/journals/archives-of-medical-casereports-and-case-study 